\title{
Reforming the educational system in Poland: The practice-based perspective
}

\section{[A. Szulc (2019). Nowa Szkoła. Szczecin: Wydawnictwo Natuli, 184 pp.]}

This year's events related to the reform of schooling system in Poland, teachers' strikes and the changes in the Cabinet of Minister of Education have resulted in the national debate on the condition of state education in Poland. In view of this situation raise questions whether it is possible to modify schooling in our country and what is the role of school in the constantly changing reality.

An important and interesting voice in the current debate is the book by Anna Szulc Nowa Szkoła (original Polish title; in English: New School; 2019). In this review I will present and analyse the education approach created and successfully implemented by Szulc in her teaching practice through the prism of my parrhesia.

The author is an experienced mathematician in a secondary school. She presents her multiannual observations on ineffectiveness of traditional Prussian approach that prevails in Polish schools e.g. teacher's control over students' behaviour and activity during the lesson, excessive testing, focusing on mistakes and showering students with failing grades, transmission of encyclopaedic knowledge, depriving students of their free, afterschool time, unfriendly atmosphere which hampers learning, inhibiting development of key competences, ignoring the latest discoveries on human brain functioning. The observation by Dorota Klus-Stańska (2012, p. 26) that the role of a teacher and the role of a student are school areas in which traditionalism is deeply-rooted, confirms Anna Szulc's insights.

Having faced all the above drawbacks and impediments in her teaching practice, A. Szulc demonstrates a proactive and innovative approach. She refers in her book to matters nagging many educators: the new role of school, teachers and students in the contemporary world; grading system; homework; misbehaviour and school climate; the need for changes in Polish schools and difficulties in introducing them.

According to the author the contemporary school should become a place that facilitates students' versatile growth and prepares them for life in the future world. The crucial aim of school is thus to educate creative, decisive and responsible young people.

The author emphasises an exceptional role of a teacher in this 'new school'. His main job is to create conditions conducive to student learning. Hence the teacher 
should specialise not only in his school subject but also in psychology, tutoring, etc. He should be a mentor who supports students' development and a guide who shows them the world and universal values. In order to meet all the above requirements the author of the book became herself an open minded and reflective practitioner who continues to improve her methods of teaching. Her ideas correspond to John Hattie's (2003) list of prototypic attributes of a great teacher.

Moreover, the author observes that a redefined role of school and teacher changes the role of the student. Young people should become active participants of their education process. It is related to gaining knowledge e.g. the authors students' participate actively in creative tasks, cooperate with peers, use mnemonic techniques, participate in classroom discussions, etc. It all leads to better understanding and improved retention. But being an active participant also implies getting engaged in setting up classroom rules, giving the teacher feedback on his work, suggesting students' own solutions to problems, deciding on their own grades, etc. Procedures used by the author in everyday school situations can really work wonders - young people gain self-confidence, but foremost, feel responsible for their decisions, education and growth.

As far as grades are concerned, the author admits she does not attach greater importance to them! What matters most is individual student's development. She appreciates even the smallest progress. Thanks to this approach the students and their parents know that gaining knowledge, not good grades, is the aim of their education. The author has created an innovative, student-centred practice: all tests can be retaken many times and the terms are adjusted to a particular student's needs; students decide which grade is final; the teacher is focused on situations when a student has gained knowledge and praises him/her with a grade; mistakes are treated as natural stages in learning and students are not criticised for making them. As a consequence, there is no problem with cheating or demonstrating the right attitude among students, which is observed as a frequent school problem (Klus-Stańska, Nowicka 2006). The procedures implemented by the author have resulted in students' greater motivation, sense of responsibility and empowerment.

Another issue discussed in the book is an ineffective use of the 45-minute-lesson. The author admits that first of all teachers usually do not start the lessons on time, secondly some time is spent on taking the attendance, thirdly, asking an individual student also seems to disturb effective brain processes and steals precious minutes of the lesson as only this particular student is engaged, while the rest of the class are only passive observers. An ineffective use of time results in giving compulsory homework - the illusory remedy for completing the curriculum, which deprives young people of valuable afterschool life. The author of the book has developed a perfect time-managing practice and resigned from setting compulsory homework. Effective education should make use of the most efficient attributes of teaching and learning and eliminate the ones that are time consuming and ineffective e.g. homework (Hattie 2008). 
A natural element of every teacher's work is dealing with students' behaviour. Traditional remedies like behaviour assessment, praises, reprimands, book and financial prizes, ratings, setting straight - Are ineffective and enhance students' external motivation. As an alternative, the author recommends using tested methods derived from the Nonviolent Communication approach. The positive school climate has been achieved by implementing methods that are perfect in their simplicity: being an understanding person, willing to support students, encouraging young people to ask questions, lively students' cooperation, stress-free assessment, student self-grading model, respecting and appreciating mistakes, appropriate relations with other people, misbehaviour as student's call for help, punishments and lack of praises.

The author's everyday teaching practice proves that school in its current format requires vast changes as it does not support students' development. Interestingly, the author aptly identifies the main obstacles to introducing changes: teaching community resistance to changes, ignoring problems, implementing façade and bureaucratic changes, teachers' professional burnout, lack of government support for bottom-up initiatives. Nevertheless, the book presents a positive vision for Polish school provided that curriculum at pedagogic faculties is regularly updated and students are adjusted to existing reality. Secondly, teachers increasingly get inspired by their colleagues' good practice. Last but not least, effective and efficient changes are to be done by practitioners. Not many stakeholders in education understand that only two participants of pedagogical action, a teacher and a student, with their separate, harmonious and synergetic activities of teaching and learning constitute successful school education (Stępkowski 2019).

The book New School is one of few practice-based Polish publications. It is a strong, honest and sensible voice we need in an era of excessive homework, private tutoring and fashion for teaching with the use of new technologies. It presents universal advice intelligible to a wide range of readers - especially teachers and students of pedagogic faculties but also parents, headteachers and even politicians responsible for the education system.

Albert Einstein once said that 'If you can't explain it simply, you don't understand it well enough'. Anna Szulc explains complex school-related problems in a comprehensive and accessible way.

\section{References}

Hattie J., Distinguishing Expert Teachers from Novice and Experienced Teachers. Retrieved from: https://research.acer.edu.au/cgi/viewcontent.cgi?article $=1003 \&$ context=research_conference_2003

Klus-Stańska D. (2012). Wiedza, która zniewala. Transmisyjne tradycje w szkolnej edukacji. Forum Oświatowe, 1(46), 21-40. 
Klus-Stańska D., Nowicka M. (2006). Nauczyciele na drodze awansu zawodowego - między

pozorem a profesjonalizacją. Problemy Wczesnej Edukacji, 1(3).

Hattie J. (2008). Visible Learning. New York: Routledge.

Stępkowski D. (2019). Kształcenie jako dobro pedagogiczne i źródło nierówności edukacyjnej W: Wrońska K. (red.). Dobra edukacji i ich pedagogiczna eksploracja. Kraków: Wydawnictwo Uniwersytetu Jagiellońskiego. 